\title{
Pengaruh Pendidikan Kesehatan Terhadap Sikap Orangtua Dalam Penanganan Awal Kejang Demam Pada Balita
}

\section{The Effect Of Health Educatioan On Parents Attitudes In The Early Treatment Of Fever Convulsions In Toddlers}

\author{
Siska Nurul Abidah ${ }^{1}$, Hinda Novianti ${ }^{2}$ \\ 1,2Fakultas Keperawatan dan Kebidanan, Universitas Nahdlatul Ulama Surabaya \\ 1Email: siskanurul@unusa.ac.id
}

\begin{abstract}
ABSTRAK
Orangtua dengan balita kejang demam merasa khawatir dan cemas apabila balita mereka mengalami demam dan suhu tubuh yang tidak segera turun. Hal ini dapat disebabkan karena ketidaktahuan orang tua tentang penanganan awal kejadian kejang demam pada balita. Tujuan penelitian ini untuk mengetahui pengaruh pendidikan kesehatan tentang kejang demam terhadap sikap orangtua dalam penanganan kegawatdaruratan kejang demam pada balita. Penelitian ini merupakan penelitian kuantitatif dengan desain quasy eksperiment desaign dengan rancangan one group pretest posttest desaign. Populasi orang tua yang memiliki anak berusia 3 bulan - 5 tahun sampel berjumlah 80 orang dengan cara Purposive sampling. Penelitian dilakukan selama 2 bulan yaitu Juli-Agustus 2020 di RW 01 dan RW 02 Kelurahan Wonokromo Surabaya. Pengumpulan data berupa kuesioner. Uji statistik menggunakan uji Wilcoxon Sign Rank Test. Hasil uji statistik didapatkan nilai signifikansi 0,000 ( $p$ value <0,005) artinya ada pengaruh pendidikan kesehatan terhadap sikap orang tua dalam penanganan kegawatdaruratan kejang demam pada balita. Pendidikan kesehatan dapat meningkatkan pengetahauan sehingga dapat merubah sikap orangtua dalam melakukan penanganan awal kejang demam pada balita.
\end{abstract}

Kata kunci : Pendidikan Kesehatan, Kejang Demam, Balita

\section{ABSTRACT}

Parents of toddlers with fever seizures are worried and anxious if their toddler has a fever and body temperature does not drop immediately. This can be caused by perents' ignorance about the early handling of febrile seizures in toddlers. The purpose of this study was to determine the effect of health education on febrile seizures on parents' attitudes in handling emergency febrile seizures in toddlers. This research is a quantitative study with a desaign quasy experiment design with a one group pretest posttest desaign design. The sample population of parents who had children aged 3 months-5 years is 80 people by means of purposive sampling. The research was conducted for 2 months, namely July-August 2020 at RW 01 and RW 02 Wonokromo Vileage, Surabaya. Dta collection in the from of a questionnaire. Statistical test using the Wilcoxon Sign Rank Test. The statistical test result obtained a significance value of 0.000 ( $p$ value $<0.005)$, which means that thhere is an effect of health education on the ettitudes of parents in handling emergency febrilr seizures in toddlers. Health education can increase knowladge so that it can change parents' attitudes in early handling of febrile seizures in toddlers.

Keywords: Health Education, Fever Convulsions, Toddlers

PENDAHULUAN

$$
\text { Kejang demam }
$$

kebanyakan terjadi pada rentang usia 3

bulan sampai 5 tahun hal ini dikarenakan

pada masa balita otak masih sangat

rentan terhadap peningkatan mendadak suhu tubuh dan memiliki insiden puncak penyakit pada usia 18 bulan serta dapat hilang usia 6 tahun (Ngastiyah, 2015). Kejadian kejang demam yang paling rawan di tahuan kedua, jika tidak ditangani deengan baik beresiko 
komplikasi (Potter dan Perry, 2015).

Menurut World Health

Organization (WHO, 2012) kejadian

kejang demam menyebabkan epilepsi di

Negara miskin sebanyak $80 \%$. Menurut

Ikatan Dokter Indonesia tahun 2017

kejadian kejang demam kebanyakan

dialami oleh anak usia dibawah 5 tahun

sebesar 2-5\%. Sedangkan kejadian

kejang demam di Jawa Timur sebanyak

2-3\% dari 100 anak (Dinkes Jawa Timur, 2020).

Penanganan kejang demam dapat dipengaruhi oleh pengetahuan. Pengetahuan yang benar serta pembelajaran yang tepat merupakan dasar dalam melakukan penanganan kejang demam (Nabiel H, 2017). Pengetahuan orangtua yang minim tentang kejadian kejang demam pada balita dapat menyebabkan kekhawatiran dan kecemasan yang berlebih.

Demam dianggap sebagian besar orang tua sebagai penyakit, sehingga orang tua akan merasa senang dan kegelisahan mereka berkurang saat demam sudah berhasil diturunkan. Sehingga terkadang Dokter akan memberikan obat penurun panas sebagai usaha untuk menghilangkan kegelisahan para orangtua padahal sebenarnya solusi tersebut tidak terlalu diperlukan (Hawari, 2016).

Menurut hasil penelitian (Jones \& Jacobsen, 2015) mengatakan bahwa kejang demam pada anak mengakibatkan peningkatan risiko kerusakan pada otak, muncul kejadian epilepsi, dan perkembangan akan terhambat. Masyarakat umum terutama orangtua masih sangat kurang informasi tentang bagaimana sikap orangtua dalam penanganan awal pada balita yang mengalami kejang demam.

Faktor yang dapat merubah perilaku seseorang salah satunya adalah pendidikan kesehatan (Notoaatmodjo, 2012). Dengan di lakukan pemberian pendidikan kesehatan diharapkan dapat menambah informasi sehingga mengubah sikap orangtua dalam melakukan penanganan kejang demam pada balita (Widagdo, 2012). Sehingga berdasarkan hal tersebut diatas peneliti tertarik meneliti pengaruh pendidikan kesehatan tentang kejang demam terhadap sikap orangtua dalam penanganan kegawatdaruratan kejang demam pada balita.

\section{METODE PENELITIAN}

Penelitian ini merupakan jenis penelitian Quasy Eksperiment 
Desaign dengan rancangan one group pretest postest desaign.

Variabel independen adalah pendidikan kesehatan tentang kejang demam dan variabel dependen adalah sikap orangtua dalam penanganan kegawatdaruratan kejang demam pada balita. Populasi orangtua yang mempunyai anak usia 3 bulan - 5 tahun dengan cara purposive sampling. Sampel yang diteliti dalam penelitian ini memiliki kriteria eksklusi antara lain :

a. Orangtua yang mempunyai balita yang mempunyai penyakit bawaan

b. Orangtua yang mempunyai balita dengan riwayat keluarga epilepsi

c. Orangtua yang tidak bersedia menjadi responden

Penelitian dilakukan selama 2 bulan yaitu Juli-agustus 2020 di RW 01 dan RW 02 Kelurahan Wonokromo Surabaya. Pengumpulan data berupa kuesioner. Setelah data dikumpulkan Data dianalisis menggunakan uji statistik yaitu uji Wilcoxon Sign Rank Test.
HASIL DAN PEMBAHASAN

Tabel 1. Distribusi Frekuensi Responden Berdasarkan Usia Ibu di Wilayah RW 01 dan RW 02 Kelurahan Wonokromo Tahun 2020

\begin{tabular}{ccc}
\hline Usia Ibu & Frekuensi & Persentase (\%) \\
\hline$<20$ Thn & 9 & 11,3 \\
$20-35$ Thn & 50 & 62,5 \\
$>35$ Thn & 21 & 26,3 \\
Total & 80 & 100 \\
\hline Tabel & $1 . \quad$ Menunjukkan hasil
\end{tabular}

sebagian kecil (11,3\%) responden berusia kurang dari 20 tahun sebanyak 9 orang dan sebagian besar $(62,5 \%)$ berusia 20-35 tahun sebanyak 50 orang.

Tabel 2. Distribusi Frekuensi Responden Berdasarkan Pendidikkan Ibu di Wilayah RW 01 dan RW 02 Kelurahan Wonokromo Tahun 2020

\begin{tabular}{|c|c|c|}
\hline $\begin{array}{c}\text { Pendidikkan } \\
\text { Ibu }\end{array}$ & Frekuensi & $\begin{array}{c}\text { Persentase } \\
(\%)\end{array}$ \\
\hline SMP & 5 & 6,3 \\
\hline SMA/SMK & 42 & 52,5 \\
\hline PT & 33 & 41,3 \\
\hline Total & 80 & 100 \\
\hline
\end{tabular}

sebagian kecil $(6,3 \%)$ pendidikkan ibu adalah SMP sebanyak 5 orang dan sebagian besar $(52,5 \%)$ pendidikkan ibu adalah SMA/SMK sebanyak 42 orang. 
Tabel 3. Distribusi Frekuensi sikap orangtua tentang kejang demam sebelum diberikan pendidikan kesehatan Di Wilayah RW 01 dan RW 02 Kelurahan Wonokromo Tahun 2020

\begin{tabular}{lcc}
$\begin{array}{l}\text { Sikap } \\
\text { Orangtua }\end{array}$ & Frekuensi & $\begin{array}{c}\text { Persentase } \\
(\%)\end{array}$ \\
\hline baik & & 23,8 \\
cukup & 19 & 76,3 \\
kurang & 61 & 0 \\
Total & 0 & 100 \\
\hline \multicolumn{1}{r}{ Tabel } & 3. & Menunjukkan hasil
\end{tabular}

sebagian besar $(76,3 \%)$ sebelum mendapatkan edukasi, sikap orangtua masuk dalam kategori cukup sebanyak 61 orang dan sisanya $(23,8 \%)$ masuk kedalam kategori baik sebanyak 19 orang.

Tabel 4. Distribusi Frekuensi sikap otangtua tentang kejang demam setelah diberikan pendidikan kesehatan Di Wilayah RW 01 dan RW 02 Kelurahan Wonokromo Tahun 2020

\begin{tabular}{lcc}
\hline Sikap ortu & Frekuensi & $\begin{array}{c}\text { Persentase } \\
(\%)\end{array}$ \\
\hline Baik & 75 & 93,8 \\
Cukup & 5 & 6,3 \\
Kurang & 0 & 0 \\
Total & 80 & 100 \\
\hline
\end{tabular}

Tabel 4. Menunjukkan hasil sebagian besar $(93,8 \%)$ setelah mendapatkan edukasi, sikap orangtua masuk dalam kategori baik sebanyak 75 orang dan sisanya (6.3\%) masuk kedalam kategori cukup sebanyak 5 orang.
Tabel 5. Hasil Uji Shapiro-Wilk

\begin{tabular}{lccc}
\hline & \multicolumn{3}{c}{ Shapiro-Wilk } \\
& Statistic & Df & Sig \\
\cline { 2 - 4 } $\begin{array}{l}\text { Skor pre- } \\
\text { test }\end{array}$ & 0,527 & 80 & 0,000 \\
$\begin{array}{l}\text { Skor post- } \\
\text { test }\end{array}$ & 0,259 & 80 & 0,000 \\
\hline
\end{tabular}

Tabel 5. Menunjukkan hasil uji Shapiro-Wilk nilai saat pre-test dan post test hasil signifikansi 0,000 ((p-value < 0.05) artinya variabel sikap orangtua sebelum mendapatkan edukasi dan setelah mendapatkan edukasi tidak terdistribusi normal, maka dilakukan uji statistik menggunkan wilcoxon-test.

Tabel 6. Hasil Uji Wilcoxon Test

\begin{tabular}{|c|c|c|c|c|c|c|}
\hline & & $\mathrm{N}$ & $\begin{array}{l}\text { Mean } \\
\text { Rank }\end{array}$ & $\begin{array}{c}\text { Sum of } \\
\text { Ranks }\end{array}$ & $\begin{array}{c}\mathrm{Z} \\
\text { hit }\end{array}$ & Sig. \\
\hline \multirow{9}{*}{$\begin{array}{l}\text { Skor } \\
\text { pre- } \\
\text { test- } \\
\text { skor } \\
\text { post- } \\
\text { test }\end{array}$} & Nega & $2^{a}$ & 30,5 & 61,00 & \multirow{8}{*}{$\begin{array}{c}- \\
7,2 \\
30^{\mathrm{b}}\end{array}$} & \multirow{8}{*}{$\begin{array}{c}0,00 \\
0\end{array}$} \\
\hline & rank & & \multirow{7}{*}{30,5} & \multirow{7}{*}{$\begin{array}{c}1769,0 \\
0\end{array}$} & & \\
\hline & $s$ & & & & & \\
\hline & Posit & $58^{\mathrm{b}}$ & & & & \\
\hline & ive & & & & & \\
\hline & Rank & & & & & \\
\hline & $\mathrm{S}$ & & & & & \\
\hline & Ties & $20^{c}$ & & & & \\
\hline & Total & 80 & & & & \\
\hline
\end{tabular}

pre test dan post test pada negative rank sebanyak 2 orang sebelum dan setelah mendapatkan edukasi sikap orangtua menurun, pada positive rank sebanyak 58 orang sebelum dan setelah mendapatkan edukasi sikap orangtua meningkat dan pada ties sebanyak 20 orang sebelum dan setelah mendapatkan edukasi sikap orangtua sama. Hasil uji menggunakan wilcoxon-test hasil nilai $\mathrm{Z}$ diperoleh -7,230 dan signifikansi 0,000 
$((\mathrm{p}$-value $<0.05)$ artinya terdapat pengaruh pendidikan kesehatan tentang kejang demam terhadap sikap orangtua dalam penanganan kegawatdaruratan kejang demam pada balita.

\section{Sikap orangtua terhadap penanganan awal kejang demam sebelum diberikan pendidikan kesehatan \\ Pada hasil penelitian}

menunjukkan hasil sikap orang tua dalam melakukan penanganan kegawatdaruratan kejang demam pada balita sebelum diberikan pendidikan kesehatan, sikap orangtua masuk dalam kategori cukup. Menurut teori Notoatmodjo pada tahun 2012 sikap adalah pikiran serta perasaan seseorang dalam menanggapi suatu objek yang tidak dapat dilihat langsung, tetapi dapat diwujudkan melalui tindakan nyata yang didukung oleh fasilitas dalam melaksanakannya. Sikap terbagi menjadi 3 komponen yaitu pikiran, keyakinan dan emosi (Miftah, 2013).

Kebanyakan orang tua saat anaknya mengalami kejang demam akan merasa cemas dan panik hal ini dapat disebabkan kurangnya informasi yang didapatkan dalam melakukan penanganan kegawatdaruratan kejang demam pertama pada balita saat dirumah.
Hal ini didukung oleh penelitian Marwan tahun 2017 mengatakan apabila penanganan pertama demam tidak dilakukan dengan benar oleh orang tua, maka dampaknya terjadi keterlambatan dalam memberikan penanganan oleh petugas kesehatan saat dirumah sakit. Hasil penelitian ini diperkuat oleh Susilowati pada tahun 2014 menunjukkan sikap orangtua dalam manajemen demam pada anak kejang demam sebelum diberikan pendidikan kesehatan masuk kategori rendah.

\section{Sikap Orangtua terhadap penanganan awal kejang demam setelah diberikan pendidikan kesehatan}

Pada hasil penelitian ini menunjukkan bahwa sikap orang tua dalam melakukan penanganan kegawatdaruratan kejang demam pada balita setelah diberikan pendidikan kesehatan masuk dalam kategori tinggi. Menurut teori Setiawati tahun 2011, pendidikan kesehatan adalah suatu upaya untuk mewujudkan perilaku hidup sehat dengan cara mempengaruhi orang lain, sasarannya adalah individu, kelompok, keluarga dan masyarakat. Harapannya setelah mendapatkan pendidikan kesehatan, pengetahuan seseorang bertambah, sehingga dapat 
mengalami perubahan sikap yang lebih baik.

Dari hasil penelitian sikap orangtua setelah mendapatkan pendidikan kesehatan menunjukkan hasil sebagian besar $(93,8 \%)$ masuk dalam kategori baik. Menurut Langging pada tahun 2018 mengatakan sikap ibu dalam melakukan penanganan kejang demam salahsatunya dipengaruhi oleh tingkat pengetahuan. Hal ini dipertegas penelitian Siriat pada tahun 2013, mengatakan bahwa informasi yang didapatkan dengan baik dapat mempengaruhi sikap seseorang sehingga dapat di praktekkan sendiri oleh responden.

\section{Pengaruh Pendidikan Kesehatan Terhadap Sikap Orang Tua Dalam Penanganan Awal Kejang Demam Pada Balita.}

Menurut hasil penelitian dengan uji statistik Wilcoxon Sign Rank Test didapatkan nilai signifikan $0,000(p$ value $<$ a 0,05) artinya ada pengaruh pendidikan kesehatan tentang kejang demam terhadap sikap orang tua dalam penanganan kegawatdaruratan kejang demam pada balita di RW 01 dan RW 02 Kelurahan Wonokromo Surabaya.

\begin{tabular}{llr}
\multicolumn{1}{c}{ Orangtua } & kebanyakan kurang \\
mendapatkan informasi tentang & temam yang
\end{tabular}

benar sehingga dapat mengakibatkan cidera tambahan. Setelah diberikan pendidikan kesehatan, sikap orangtua menjadi lebih baik dan mengetahui bagaimana dampak jika terlambat dalam memberikan pertolongan pertama. Penanganan awal kejang demam diharapkan dapat mencegah cidera, suhu tubuh bisa turun dan pencegahan infeksi (Sudarmo, 2012).

Menurut teori Notoatmodjo tahun 2012, pendidikan kesehatan merupakan bagian dari proses untuk memotivasi sasaran guna meningkatkan pengetahuan akan kesehatan, sehingga mempunyai perilaku dan sikap yang lebih baik lagi. Perbedaan rerata pada sikap orangtua dalam penelitian ini dapat dinilai dari metode pendidikan kesehatan serta tata cara saat pemberian materi.

Hal ini didukung oleh penelitian Sudarto pada tahun 2018 menunjukkan bahwa pendidikan kesehatan berpengaruh terhadap sikap orangtua dalam menangani kejang demam pada anak. Penelitian ini juga didukung oleh penelitian Puspitasari,dkk tahun 2019, mengatakan bahwa pengetahuan dan sikap ibu dalam pencegahan kejang demam berulang lebih baik setelah mendapatkan edukasi kesehatan.

\section{SIMPULAN DAN SARAN}


Terdapat pengaruh pendidikan kesehatan tentang kejang demam terhadap sikap orang tua dalam penanganan kegawat daruratan kejang demam pada balita di RW 01 dan RW 02 Kelurahan Wonokromo Surabaya. Hasil penelitian ini diharapkan dapat menjadi promotif dan preventif yang dapat menurunkan angka kematian dan kesakitan balita dan untuk masyarakat khususnya orangtua diharapkan dapat mengambil tindakan pertama yang tepat saat terjadi kejang demam pada balitanya.

\section{DAFTAR PUSTAKA}

Dinas Kesehatan Jawa Timur. (2015). Profil Kesehatan Jawa Timur 2015. Jawa Timur: Dinkes Jatim

Hawari, R. P. (2016). Management Stress, Cemas dan Depresi. Jakarta : FK UI.

Jones, T., \& Jacobsen, S.J. (2015). Childhood Febrile Seizures: Overview and Implications. International Journal of Medical Sciences.. ISSN 1449-1907

Langging, A., Wahyuni, T. D., \& Sutriningsih, A. (2018). Hubungan Antara Pengetahuan Ibu dengan Penatalaksanaan Kejang Demam Pada Balita di Posyandu Anggrak Tlogomas Wilayah Keja Puskesmas Dinoyo Kota Malang. Nursing News, 3, 643-652
Marwan, R. (2017). Faktor Yang Berhubungan Dengan Penanganan Pertama Kejadian Kejang Demam Pada Anak Usia 6 Bulan - 5 Tahun Di Puskesmas

Miftah Toha. (2013). Perilaku Organisasi Konsep Dasar \& Aplikasi. Jakarta : PT Raja Grafindo Persada

Nabiel H. (2017). Buku ajar keperawatan anak.Yogyakarta: Pustaka Pelajar

Notoaatmodjo, S. (2012). Pendidikan dan Perilaku Kesehatan. Jakarta: RinekaCipta.

Ngastiyah. (2015). Perawatan anak sakit.Edisi 2. Jakarta: EGC

Potter \& Perry. (2015). Buku ajar fundamental keperawatan; konsep. Proses dan praktik Edisi 4 Volume 2. Jakarta: EGC

Soedarmo. (2012). Buku ajar infeksi dan pediatri tropis. Jakarta: Ikatan Dokter Indonesia

Sudarto. (2018). Pengaruh pendidikan kesehatan terhadap tingkat sikap ibu dalam menangani kejang demam pada anak di wilayah kerja puskesmas pakis.

Setiawati, S. (2011). Proses Pembelajaran dalam Pendidikan Kesehatan. (Agung, Ed.). Jakarta: Trans Info Pertama.

Siriat, N. A. J., Rustina, Y., \& Waluyanti, F. T. (2013). Pemberian informasi meningkatkan pengetahuan, sikap dan ketrampilan orang tua dalam penanganan demam pada 
anak.Jurnal Keperawatan

Indonesia, 16(2): 101-106.

Widagdo. (2012). Masalah Dan Tatalaksana Penyakit Anak Dengan Demam.Jakarta : Sagung Seto

WHO. (2012). Angka Kematian Bayi. Amerika. World Health Organization.

Puspitasari, J.D. Nurhaeni, $\mathrm{N}$ dan Allenidekania (2019). Edukasi meningkatkan pengetahuan dan sikap ibu dalam pencegahan kejang demam berulang. JPPNI Vol.04/No.3 